\title{
Historical Consciousness in the Focus of Sociological Enquiry
}

Jiří Šubrt, ${ }^{1}$

Faculty of Humanities, Charles University in Prague, Czech Republic ${ }^{2}$

\begin{abstract}
Historical Consciousness in the Focus of Sociological Enquiry. This article attempts to elaborate a theory of historical consciousness which could apply to the area of empirical sociological enquiry. Its essential idea is that it is possible to view historical consciousness as an "entity" shaped by the interplay of four components: a) lived historical experience (lived personally, eventually transmitted through interpersonal contact), b) ideology, particularly state ideology and ideology of political parties, c) knowledge produced by historiography and historical science, d) collective memory.
\end{abstract}

Key words: historical consciousness, collective memory, lived historical experience, ideology, historical science

Historické vědomí v ohnisku sociologického zkoumání. Článek přináší nástin teorie historického vědomí, která je určena k aplikaci $v$ oblasti empirického sociologického zkoumání (dotazování). Základní myšlenkou této koncepce je, že historické vědomí Ize nahližet jako „entitu“, jež je tvořena souhrou čtyř komponent, kterými jsou: a) prožitá historická zkušenost (prožitá osobně, prípadně přenášená v interpersonálním kontaktu), b) ideologie, zejména státní ideologie a ideologie politických stran, c) poznatky produkované dějepisectvím a historickou vědou, d) kolektivní pamět'.

Kl'účové slová: historické vědomí, kolektivní pamět', prožitá historická zkušenost, ideologie, historická věda

Today in post-communist countries the concept of historical consciousness seems untrustworthy to many intellectuals. Its lack of credibility lies in its associations with previous Marxist ideology, historical materialism, theses regarding the dialectics of being and consciousness or the importance of class consciousness. Moreover, this concept may even evoke memories of the theory of social consciousness that was developed by Soviet theorists during the seventies and eighties (one of the leading theoreticians being A. K. Uledov 1973) and imported into other countries of the so-called socialist bloc (see e.g. Jiri Vanek 1980). It is no wonder that most scholars in post-communist countries, when they engage in people's relationship towards the past, prefer the concept of social (collective, cultural or historical) memory. In the past two

${ }^{1}$ In the preparation of this article, the author used the suggestions and comments of Štěpánka Pfeiferová.

${ }^{2}$ Address: Doc. PhDr. Jiř́ Šubrt, CSc., Department of Historical Sociology, Faculty of Humanities, Charles University in Prague, U Kř́žže 8, 15800 Prague 5, Czech Republic. E-mail: jiri.subrt@fhs.cuni.cz

Slovak Journal of Political Sciences, Volume 14, 2014, No. 2 
decades the concept of social memory has enjoyed the overwhelming (one might even say exclusive) interest of researchers, ${ }^{3}$ becoming the subject of innumerable studies, and an instrument of contemporary political and ideological disputes and conflicts. The concept of historical consciousness is, however, rather marginal and forgotten by many. Nevertheless it cannot be completely ignored.

Expressions of social memory and historical consciousness are overlapping, but cannot be identified with each other, and one cannot permanently replace the other. The outline given by Jürgen Straub can serve as a starting point of our interpretation. He combines historical consciousness with historical narrative construction and historical meanings in the field of the human mind (Straub 2005: 48-49). Peter Seixas defines historical consciousness as well as individual and collective understandings of history, which are influenced by cognitive and cultural factors (Seixas 2004: 10). It is essential that part of historical consciousness is a historical understanding of the present and the future. Jörn Rüsen characterizes historical consciousness as a specific mode of orientation which is used in solving current situations (Rüsen 2004: 66). So already we can see that historical consciousness is to be understood not only as a complex of knowledge, perceptions and ideas about the past, but primarily as an awareness of certain specific contexts (or continuities, discontinuities and changes) between the past (stored in the collective memory), the present and

3 In recent decades French scholars especially have set the tone of research on collective memory (Šubrt, Pfeiferová 2010). Some of the research that has been conducted by the historian Pierre Nora, known for his project Les lieux de mémoire (1984 - 1992), also extends into sociology. Tzvetan Todorov (1998) in France, known for his studies on people's behaviour in extreme situations during the Second World War, draws on the method of oral history. In sociology, Gérard Namer (1987, 2000) has been instrumental in rediscovering and finding contemporary applications for the work of Maurice Halbwachs, and he emphasises the plurality of forms of collective group memory and shows how this concept can become the subject of sociological research. Danièle Hervieu-Léger, the author of La religion pour mémoire (1993), departs from the premise that every religion encompasses in itself a specific activation of collective memory. The philosopher Paul Ricœur, in his book La mémoire, l'histoire, l'oubli (2000), examines from a historical-philosophical perspective the relationship between experience and historical memory, responsibility for the past, questions of guilt, and the space for forgiveness. In the German-speaking countries, the subject of social and cultural memory has been most notably addressed in the work of Jan Assmann (2001, 2007) and Aleida Assmann (2006, 2009). In the United States current topics of research and policy of memory are being developed mainly by Jeffrey K. Olick $(2007,2011)$. 
the future; as a consciousness which has contributed to shape people's attitudes towards the present and the future.

The precise problem of historical consciousness becomes apparent when we start thinking comparatively. It is useful to recall that during the $19^{\text {th }}$ century and early $20^{\text {th }}$ century there was a widespread sense that history had a certain meaning and direction. It was a period dominated by what is often called "historism". At that time, past and the future horizons had a different form and depth than they have today. The past suggested trends directed towards specific goals across eras, in which the fulfilment of a historical plan was to be accomplished. The future had the character of a mainland to which - after a long trip - people would apparently soon arrive. At this time faith in progress, in large emancipatory "stories" announcing the arrival of happy tomorrows, was still very much alive. Also notable, however, were decadent moods of fin de siécle in which the fate of mankind was associated with the idea of doom and ruin. Learning from the incidents and disasters of the $20^{\text {th }}$ century, this trust in the sense of history and the "grand narratives" - as highlighted by contemporary thinkers (Lyotard 1993) - has evaporated. On the contrary, a hundred years later the consciousness of late modernism concentrates on the present, and historical consciousness is somewhat "flattened". For people living in the early $21^{\text {st }}$ century the past is another country, their historical consciousness has a different nature.

Today's culture, following the great trauma of the $20^{\text {th }}$ century, is characterized by the fundamental mistrust and scepticism towards the "great narratives" of history (theory of history, theory of progress) and the future (emancipatory projects, ideology). As a result, there is a quite reasonable hypothesis that today's people cannot see - in comparison with their predecessors - the causes for the present, or look back to the past, or look with hope and expectations to the future. Despite this, interest in history is not foreign to many people, which is reflected inter alia in the popularity of historical literature and film. So the question is, what can history offer today's man? Historian Miroslav Hroch (2010: 37) speaks about nine possible reasons for this interest:

1. History is a storehouse of stories that we may enjoy, believe and understand.

2. Detection of historical facts is an intellectual challenge.

3. Past events are or should be a source of enlightenment.

4. History provides us with personalized role models, but also warning examples.

5. History is a sequence of events that we want to understand, while at the same time we want to understand the contemporary world. 
6. In this effort, we may be also affected by basic history and by its current general background and principles.

7. Past events can be a source or justification of current demands (gender, group or national).

8. The past is a source of values that enables us to understand our merit and gives insight into the meaning of our existence (in terms of individuals and groups).

9. History provides arguments and incentives for self-identification and group cohesion (Ibid.).

It should be clear from the above list that history's relevance varies for different groups of people. From a societal perspective, the final point may be regarded as particularly important. The past's importance is above all in terms of our collective identity and two fundamental questions connected with itwho we are and where we are going. History reinforces this identity by the consciousness of a jointly shared descent, adds arguments for the assessment of our current status, and creates a presumption for searching for and shaping a common future.

At the outset it is important to note that as yet no comprehensive, welldeveloped theory of historical consciousness that we could reliably draw on exists. What is available in this field at present is a certain set of assumptions that on the level of empirical research could be used to formulate research questions and working hypotheses. The first assumption is that historical consciousness can be understood as an entity (an element of human knowledge) that has a certain content, selected aspects of which can be observed and measured in particular parts of the population with the aid of sociological research instruments. Other assumptions can be formulated as follows: a) the character of historical consciousness is fundamentally dependent on the interests and knowledge that inform the relationship people have to history; b) a constituent part of historical consciousness is certain (often relatively vague) ideas about the nature of the historical process (the forces that influence history and the nature of its course) and about the links between the past, the present, and the future in general; c) an evaluative view of the history of one's nation or country forms an important part of historical consciousness; d) historical consciousness is not a constant entity, but rather is itself historically variable and is above all influenced by general socio-political circumstances.

This approach to historical consciousness is inspired by the concept of the sociology of knowledge, specifically its wider interpretation as formulated by Peter L. Berger and Thomas Luckmann (1999: 21), according to which the sociology of knowledge should encompass everything that a given society considers to be knowledge. This means not so much the great bodies of 
knowledge embodied by religion, ideologies, utopias, art and science, but rather the kind of (general) knowledge or historical knowledge possessed by 'ordinary people' as the actors in everyday social life. We are mainly interested in how people view history and what significance they ascribe it. Understood this way, historical consciousness to us is more than just a matter of theoretical reflection, it is also the subject of empirical research.

\section{Components shaping historical consciousness}

The concept of historical consciousness has been used and elaborated in a number of professional contexts. The first was in German philosophy, where the concept Geschichtsbewußtsein appeared. In the $19^{\text {th }}$ century it appeared in the philosophy of life of Wilhelm Dilthey (1910/ 1981), followed in the $20^{\text {th }}$ century by Hans Georg Gadamer (1979) in his hermeneutical philosophy. Geschichtsbewußtsein in this concept is seen as a prerequisite for the understanding and interpretation of past events. It is a consciousness able to judge the past according to itself, not the standards and prejudices of the present time.

In the 1970's some German experts on the issue of teaching history began to work with the concept of Geschichtsbewußtsein (Bodo von Borries (1988 ,1990, 1995), Karl - Ernst Jeismann (1988), Hans Jürgen Pandel (1987), Jörn Rüssen $(1994,2001)$ and others), but in a somewhat different context than that presented by philosophical hermeneutics. In their approaches, the term is associated primarily with the question of educative activities and meaningful connections between the idea of the past and orientations towards the present and the future.

Other suggestions then came in the 1980's from the area of narrative psychology, which developed particularly in the U.S. (Jerome S. Bruner (1990), Theodore R. Sarbin (1986)), but which also found expression in Germany (Jürgen Straub $(1998,2005)$ ). This psychological direction, working with the concept of Historical Consciousness (Historisches Bewußtsein) ${ }^{4}$, emphasized that people view their lives as stories whose versions they present to others. olving current life situations.

In the discussions that have taken place among historians in the Czech environment, historical consciousness used to be characterized in two different ways $^{5}$. While some perceive it as a rather vague general impression of history,

${ }^{4}$ The term Historisches Bewußtsein gradually pushes next to the term Geschichtsbewußtsein even in Germanenvironment. See,e.g. (Straub 1998, Georgi-Ohliger 2009).

${ }^{5}$ In the Czech Republic these discussions have not yet found their way (apart from texts published before 1989) into representative publication outputs, which could 
as a state of mind dependent on the nature of time and subject to variability, others tend to reduce it to a summary of the knowledge of history held by a certain group or community. In this latter approach, historical consciousness based on the reception of professional expertise is used to distinguish historical awareness as the summary of knowledge that has non-historiographic, i.e. nonspecial character.

Tendencies in world literature correspond rather with the first of the two mentioned approaches. Historical consciousness is not just a set of knowledge, perceptions and ideas of the past, but especially knowing certain contexts (let us say continuity, discontinuity and changes) between the past (stored in the collective memory), the present and the future; it is consciousness that helps to create attitudes towards the present and the future. This consciousness is structured in some way, and these structures can be subjected to crossdisciplinary research (from the perspectives of history, sociology and psychology).

Historical consciousness can be defined as an "entity" shaped by the interplay of certain components. One of these components is a lived historical experience (lived personally, eventually transmitted through interpersonal contact). Another is ideology, particularly state ideology, as states and their regimes use ideological interpretations of history for their legitimation; a certain role is undoubtedly played by the ideology of political parties. The third component (not in terms of importance) is the knowledge produced by historiography and historical science. The fourth is what is called "collective memory". In addition to these components other influences can be consideredfor example the ways that culture, family, school, religion, art and media express themselves. These effects, however can be considered under the abovementioned four headings, as through them comes knowledge from livedthrough historical experience, ideological or scientific knowledge, and collective memory.

It is worth adding that the four mentioned essential components (livedthrough historical experience, ideological interpretation of history, and pieces of knowledge of historiography and historical science and collective memory) are not completely separate. Boundaries between them are not clearly drawn but rather blurred; individual areas overlap. Nevertheless for clarity of thought it is useful to distinguish them.

attempt to find a more elaborate definition of historical consciousness. Traces of these discussions, however, can be found on various websites. Czech historiographers that used term historical consciousness include J. Křen, Miroslav Hroch, Z. Beneš and many more. 
Experience has the character of a knowledge which is different from the knowledge acquired by learning, reading or studying, and it can sometimes be in sharp contrast. Historical experience, unlike other types of experience - often of a partial or specific nature -, is a quite comprehensive category close to what is regarded as life experience; both types of experiences overlap, but they cannot be declared identical. Various individual experiences are frequently transferable and communicable with difficulty. By contrast, historical experience is a conception logically related to the content of collective (group, generational, social or national) character in two senses: first, because large groups of people have been exposed to certain historical events, and then because these lived-through events become the subject of collective reflection and interpersonal communication in which the experiences and lessons learned from them are transferred to others, including members of subsequent generations, especially by language tools.

Ideology represents a relatively complete set of views, ideas and values, based on the formulation of the interests of a certain group, class or state. Ideologies are above all associated with areas of policy, but also impact other spheres of social life. In the social sciences they used to be considered doubleedged: positively they act as a kind of social glue integrating the collective body; negatively they are criticised as part of a "false consciousness" (Marx), imposed upon people to justify or legitimize certain forms of social organization, power manipulation or oppression.

Dealing with historical consciousness, it is necessary to pay special attention to state ideology. Many inspiring ideas on this subject have been formulated by Pierre Bourdieu, who speaks of "symbolic order" and "symbolic violence"; the education system and compulsory public education has become their instrument. This is how the state instils common forms and categories of perception and thinking, understandings of the social framework, cognitive structures and the "state form of classification", thereby creating the conditions for common habits (mental structures), which are prerequisite for achieving a specific type of social consensus (Bourdieu 1998: 88-89). Thus the state contributes to the formation of what is called the identity or national character.

Historiography, as the systematic recording of events and processes occurring in the past, is the predecessor of today's historical science, which tries by means of professional methodology to obtain, critically analyze, systematize and explain findings related to history. Contemporary historical science has many sub-disciplines which focus on exploring the history of the world, national history, territorial history, the history of human culture, politics, economy, everyday life, etc.

Collective memory is composed of contents which can be mythical conceptions, legends, memories of historical events and personalities, traditions 
or customs. Halbwachs's concept of collective memory assumes that collective life is a source of both memories themselves, and also the terms which these memories embody. Different communities of people as subjects of collective memory constitute the social frameworks in which the specific contents of this memory are located. Individual memory is a place of specific interconnection of collective memories of various social groups. By contrast, in terms of the group the key issue is the distribution of knowledge among its individual members. Someone who participates in the collective memory thereby certifies his or her group affiliation.

In contemporary humanities, great attention is paid to the relationship between historical science and collective memory. Similarity and continuity in the standing of the group is emphasized by collective memory, according to Halbwachs, while history perceives discontinuity and difference. Group memory has a tendency to emphasize its own distinctness from its environment, which means what differentiates the group's history from those of other groups, and what is considered unique to it. History, meanwhile, levels out all such differences and reorganizes its facts in a homogeneous historical space (Halbwachs 1950: 74-75).

Pierre Nora talks about the situation in Western countries. The separation between collective memory and history, which for a long period overlap, comes when a spontaneous national memory, representing the transfer of memories from generation to generation, begins to be replaced by a deliberate and tactical construction of national history within the framework of history. Today, due to this separation, memory and history may contradict each other (Nora 1984: XIX).

Paul Ricoeur (2000) believes that while history is primarily about verification and finding truth, the main ambition of memory - involved in the construction of identity of individuals and groups - is to maintain loyalty to roots. In Ricoeur's eyes both goals are legitimate, but need to be balanced so as restricting neither memory nor history. History, which views the past detachedly, seeking an objective view on past events, enables the memory of individual groups to lose their exclusivity and opens the way to dialogue.

We have seen that the lived historical experience, (state) ideology, findings of historians and collective memory, represent mutually interacting components of historical consciousness. For a further shift in our thinking we were inspired by the American sociologist Talcott Parsons and his AGIL scheme, which we will use as a kind of heuristic model. Prerequisite for the application of Parsons' approach is the notion that historical consciousness can be regarded as a social system. Social systems consist of communications in which certain meanings are communicated; in this case specific meanings with historical content. 
Any social system, according to Parsons, can endure only if it ensures the implementation of four basic functions, which are: adaptation (A), achieving goals (G), integration (I) and maintenance of latent cultural patterns (L) (Parsons 1971: 55). In Parsons' systematic models each of these four basic functions were associated with a certain functionally specialised sub-system.

In our case function (A) can be combined with lived historical experience, (G) with the ideological interpretation of history, (I) with historical scientific knowledge, (L) with collective memory. Adaptation (A) we understand as "(re)definition" of a current situation resulting from a specific historical event. Goals (G) can be combined with the selection of historical subjects serving legitimization mechanisms. Integration (I) is brought about by individual conceptions of historical science conceiving a coherent, internally integrated and logically organized complex. Maintaining latent cultural patterns (L) is a matter of collective memory, whose task is to transfer the most important contents from the past to present.

A point to note is that Parsons' considerations do not end with a simple breakdown of four basic functions and subsystems, as two other important systemic aspects are highlighted. The first is that systemic differentiation occurs within the individual subsystems and again has the form of AGIL scheme. The second is that, between these functionally differentiated subsystems, mutual communication and interpenetration take place.

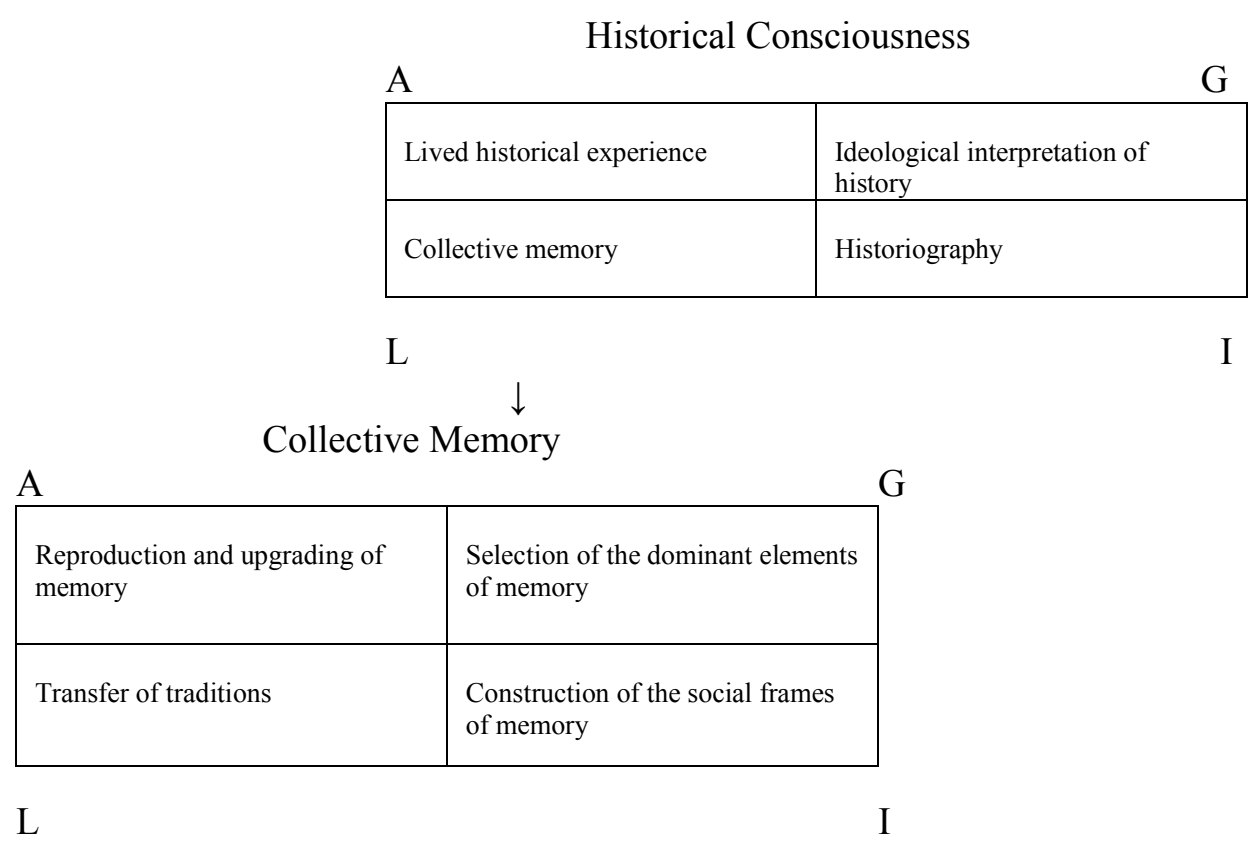


The relationship between historical consciousness and collective memory may be apprehended by analogy with the world of computers. Historical consciousness and collective memory are interrelated; the relationship can be described as interdependent. This interdependence is similar to that between computer programs on the one side and a computer memory and databases on the other. Computer programs are dependent on computer memory, where they are stored. Even though these programs can exist without data, if they get some content, the data stored in databases are necessary. The same is true in reverse: data stored in databases of computer memories may also exist independently, but to work with them a certain program is needed.

In the case of collective memory, we can identify four types of operations which correspond to the basic system functions expressed in the AGIL scheme. The adaptation of the system of collective memory (A) can be looked upon as reconstruction and memory up-date in its capacity for the constant remaking of representations of memories on the basis of present requirements. The image of the past is constantly changing according to the events, priorities and interests of present society. The setting of memory dominants corresponds to the achievement of goals (G). The collective memory works selectively. At each moment, it is based only on those memories that are useful for the legitimizing interpretation of the past, contributing to the strengthening of collective identity. The function of integration (I) corresponds to the structure of what Maurice Halbwachs calls "the social framework of the memory." These frameworks represent a kind of organization of memories or some structure of representations, providing individuals with orientation points in space and time and allowing them to remember and localize evoked memories. Maintaining latent cultural patterns (L) is represented by the transmission of tradition, rules and customs that have existed from- so to speak- time out of mind, and their transmission from generation to generation.

Maurice Halbwachs has given his opinion on the issue of the adaptation of the collective memory to the present. He attributes to collective memory the ability of constant reconstruction and therefore the continual re-actualization of reference frames according to the current situation (Halbwachs 1994: 279). The past is not maintained as such in any memory, but in the form in which the society captured it at any particular time and specific social context. To keep the memory alive, it must conform to the current needs of existing society. Therefore the image of the past must be repeatedly reproduced in accordance with the priorities, interests and requirements of the present.

Determination of the dominants of memory is related to the difficulty once pointed out by Henri Bergson (1896/ 2003). Human life, according to the author, is associated with the continuous creation of memories. In our mind these memories are given varied weight through selective retrieval. The French 
philosopher justifies this selectivity by the practical aspect of usefulness; the memory is updated if - so to speak- it comes in useful. Reflections on dominant memories are found even in Halbwachs (1994: 290); the collective memory in his concept selects those elements from the past which shape the identity of the given group partly by emphasizing the uniqueness of the group, and partly by arousing feelings of time's passage. The theme of selectivity is also one of the central problems of Paul Ricoeur's concept of "work of memory" (Ricoeur 2000). Even for him, memory is a means of selecting what should not be forgotten, and the intellectual construing of the past.

As for integration - memory, according to Halbwachs, constitutes, makes functional and reproduces in social frameworks created by people living in society; within these frames our memories are evoked and fixed; the weighted recollection of something is determined by them. These frameworks are not rigid but dynamic structures formed by elements that represent and organize our recollection. They include orientation points in space and time: historical, geographical, biographical, political concepts, common experience and familiar perspectives (Kvasničková 2005: 35).

Tradition ensures the maintenance of latent cultural patterns. Tradition usually means a cultural heritage transmitted from generation to generation. The contents of this heritage are diverse and consist of cultural patterns, religious beliefs, myths, rumours, legends, rules, instructions, recipes, traditions, customs, manners and rituals. Social groups constitute themselves on the basis of common recollection; they protect and guard their traditions. Important to this are the uniqueness resulting from differentiation from the surrounding world, consciousness of identity, and the time duration ensured by carefully memorised facts and their selection. Anthony Giddens (2000: 52) points out that much of what we think of as traditional, and steeped in the mists of time, is actually a product at most of the last couple of centuries, and is often much more recent than that. Some traditions, the author claims, were "fakedup" or "artificially manufactured". From ancient times, there has been a tendency to modify and complement the past, which is evidenced by, inter alia, a number of historical forgeries.

The AGIL scheme theoretically describes how historical consciousness and collective memory function as systems that handle a particular type of human knowledge (this processing takes place in a way that is inherent in individual subsystems and their mutual cooperation). But this scheme does not constitute the only structure which must be taken into account; other structures can be observed in historical consciousness and collective memory. One of the essential characteristics of both entities is that they have vehicles, which are individuals, groups, classes, strata, generations and, after all, society as a whole. Both systems have certain means of institutional support and 
information. Another essential feature is also the processing of certain information with regard to its time-space and factual subject matter. It follows that at least seven structures in historical consciousness and collective memory can be identified, which mutually intersect and influence each other:

- Systemic Structure (described using AGIL scheme);

- Institutional Structure (educational system, archives, institutes, museums, memorials, holidays, memorial ceremonies);

- Structure of information resources (literature, education, media);

- Stratification Structure (differentiation of classes, strata and social groups);

- Generational Structure;

- Gender Structure;

- Content Structure (differentiation of information in time, space and substance).

The shaping principles of these structures produce different types of discourse $^{6}$ which may come into mutual confrontation. The essential thing is that the individual systems process history uniquely, which generates a certain polycontextuality: one historical event (e.g. liberation in the year 1945) is viewed in different contexts, and thus looks different with respect to livedthrough experience, ideological interpretation, historical science or collective memory; in addition, the approach can be differentiated to reflect social classes, groups and generations, and can be classified into different content frames (temporal, spatial and substantive). As a result, there can be various disagreements, and even attempts to acquire the dominant position in relation to other systems and discourses, which may be the goal of ideology or historical science. The passionate polemics which have taken place in this field indicate that the matter of historical consciousness and memory is not just an academic problem, but also very serious political issue.

Historical consciousness among the population of post-communist countries developed for decades under the influence of power-political pressures, social changes and even hard-earned life experience revealing this consciousness to be fragile, manipulable, vulnerable, and particularly in non-democratic societies, subjected by power-political pressures to frequent abuse.

Findings that empirical sociological research brings on this issue (Šubrt 2010) show that historical consciousness is not a permanent set of ideas about the past, characterized by stability and permanence, but rather something that is

\footnotetext{
${ }^{6}$ Discourse of historical experiences e.g. manifested most clearly in the inter-individual communication, the discourse of ideological interpretation in the political argumentation, the discourse of historians on the pages of professional books and magazines, the discourse of collective memory in imaginative literature, film, fine arts and media.
} 
changing and developing over time. This is consistent with the assumption once formulated by American philosopher and sociologist George Herbert Mead, that people keep changing their ideas about the past (and also the future). This happens as a result of the emergence of new circumstances that put what has happened or is likely to happen in a new light. After exposure to fresh experience, people revisit their past, looking at it from another perspective and accordingly adjusting future actions and expectations (Mead 1959: 1-31). Peter L. Berger (1991: 56) argues similarly, noting that we reconstruct the past to reconcile it with the present and our current views. History is, as the author says, ductile, malleable and variable depending on how we repeatedly interpret and explain the past.

Such selectivity characterises historical consciousness. Historical consciousness may involve the displacement of unpleasant events and experiences; typical phenomena are the elimination of certain topics, but also the rewriting of history, creation of new myths, or revival of old wounds and resentments.

\section{History as a life's teacher}

Historia magistra vitae est - history is a life's teacher - Latin scholars used to say ${ }^{7}$. Although this statement is still repeated today, the question is how it sustains its relevance in the present. It is generally held that from the past one can draw lessons for today, especially in the sense that it is possible to avoid errors that proved deadly in the past. But on the other hand, it seems that we are not quite able to learn, so we have no choice but to reprise our mistakes. However the problem is generally more complicated and is not dependent only on our willingness and tendency to be influenced by historical experience.

Historian Miroslav Hroch points out that the past can be a source of wisdom only if we believe that historical changes have causal links which can be identified and analysed in a rational, causal way (Hroch 2010: 44). With this in mind he draws attention to the fact that our relationship to the past transforms within the societal context. It looked different in the $19^{\text {th }}$ century dominated by "historicism", with the idea that history has a legitimate motion and direction, and it looks different today, when trust in the sense of history is missing.

Systems theory suggests that the assumption under which history is life's teacher is somewhat problematic, as history has lost its character as a

${ }^{7}$ This statement wastakenin an abbreviatedversion from theCicero's treatise on therhetoric De Oratore, in whichthe authorsays:Historia est testis temporum, lux veritatis, vita memoria, magistra vitae, nuntia vetustatis - History is the witness of the times, the light of truth, the life of memory, the teacher. 
model (Luhmann 1988: 107). History can serve as a model for the future only if the past and future are ultimately the same (Bergmann 1983:474). However, contemporary society is dynamic, escaping from and increasingly differing from its past. Thus the simple application of the idea that we should learn from the past becomes questionable. Some lessons undoubtedly are more durable, but others become outdated over longer or even shorter time-spans.

Everyone who deals with the past is confronted with the problem of how something that irrevocably happened in a certain way is not considered fixed by future generations, but malleable. This issue was encountered by George Herbert Mead. The starting point of Mead's thinking is encapsulated in the title of one of his studies, "The Present as the Locus of Reality". The Author associates reality only with the present, not the past or future (Mead 1959: 131). People are limited to life in the present. They of course can conceive things in the past or the future, but this takes place in the present. The past and the future are only the subject of thinking and their locus is in the mind. The true past as well as the real future is inaccessible, but can be accessed through the mind in the present, whereby we can exceed the present.

Mead is aware that we are used to understanding history as irrevocable. He thus explains how the past can be at once irrevocable and revocable. The past is irreversible in the sense that we cannot change or undo things that have occurred. But in their importance and the way that they are stored then plucked from memory, the past is revocable, and as hypothetical as is the future. It is instantly transformed and re-framed as another past according to the viewpoint of the present and we, as G. H. Mead says (1936: 416), cannot know what Caesar or Charlemagne will look like in the next century.

In this context, there is a need to see the phenomenon of historical revisionism, about which it can be said - with regard to book production in recent years - that it is becoming almost a fad. It is difficult to determine to what extent the current historical literature review is focused on reinterpretation of the current views based on a real effort to bring a new and better understanding of historical events reflecting new discoveries, and to what degree it is the answer to an "ideological" order, or how much it is motivated by the individual efforts of particular scholars to draw attention to themselves from under inexhaustible amount of literature by provocative or shocking titles. Nevertheless the fact remains that in some cases the consequences of revisionist approaches (namely so-called negationism) are assessed as socially so serious and dangerous (in particular any questioning of the Holocaust), that it is considered necessary to defend against them through legislative measures and criminal penalties.

In the functioning of historical consciousness and collective memory it is as shown by some researchers - more important what the handed-down opinion 
is on historical events than what their interpretation is from the historical scientific point of view. We may recall in this context the well-known Thomas theorem. One of the key theses of symbolic interactionism and interpretive sociology is the definition of the situation, formulated by W. I. Thomas, that If people define a situation as real, it is real in its consequences (Thomas 1965:114). Interpretive sociology places great emphasis on understanding how people perceive the world around them. What is important is not what reality is, but how actors themselves see and understand it, because they then act accordingly, and their conduct produces real consequences. In our case it is possible to state that it can often be more important what people think about the past than what it really was, because this image of the past - no matter if partially or even completely false - can be a major motivating force in the present. This is also highlighted by Jan Assmann (2001: 50), who claims that what is important is not factual, but remembered history. In this sense even the myth is real to the extent that it is remembered and celebrated. What is important is its normative and formative power.

The national myths that were created during the rise of nationalism played and still to some extent play an important role. During the $19^{\text {th }}$ and $20^{\text {th }}$ century certain myths became a significant mobilizing force for some nations and social groups, sometimes lethally so. Many such myths survive in the historical consciousness and collective memory to the present day. Against historical myths used to be placed historical science. As the highest form of cognitive and theoretical work, based on a systematic and rational way of understanding reality, science defines myths critically, but not only that; it tries to explore them scientifically, clarifying the reasons for their existence and the ways they operate. Many contemporary scholars, however, point out that maintaining the efforts to define in the spirit of Enlightenment Rationalism the demarcation line between the logo and the myth is not enough, because in history there are no discrete phenomena. After all even historical science cannot be sufficiently resistant to some myths; particularly when they become part of state ideology or political parties and from there influence the contemporary educational and scientific policy. The task of sociological research in historical consciousness is not to solve these problems, because in principle they are not solvable through this approach. However, it is important that research analyses and uncovers the social and epistemological assumptions on which historical consciousness based. The answers which sociology comes by in this fashion, have not only a professional, but also a general human significance.

\section{BIBLIOGRAPHY}

ASSAMANN, A. 2006. Der lange Schaten der Vergangenheit: Erinnerungskultur und Geschichtspolitik. München: Beck. 
ASSMANN, A. 2009. Erinnerungsräme: Formen und Wandlungen des kulturellen Gadätnisses. München: Beck.

Assmann, J. 2001. Kultura a pamèt': Písmo, vzpomínky a politická identita v rozvinutých kulturách starověku. Praha: Prostor.

AsSMANN, J. 2007. Religion und kulturelles Gadätnis. München: Beck.

Berger, P. L. 1991. Pozvání do sociologie. Praha: FMO.

Berger, P. L., Luckmann, T. 1999. Sociální konstrukce reality: Pojednání o sociologii vědění. Brno: Centrum pro studium demokracie a kultury.

BergmanN, W., 1983. „Das Problem der Zeit in der Soziologie.“ In: Kölner Zeitschrift für Soziologie und Sozialpsychologie. Vol. 35., No. 3: 462-504.

Bergson, H. (1896) 2003. Hmota a pamét'. Praha: OIKOYMENH.

BORRIES, B. von 1988. Geschichtslernen und Geschichtsbewußtsein. Stuttgart: Klett..

BORRIES, B. von 1990. Geschichtsbewußtsein als Identitätsgewinn? Fachdidaktische Programmatik und Tatsachenforschung. Hagen: Margit Rottmann.

BORRIES, B. von 1995. Das Geschichtsbewußtsein Jugendlicher. Erste repräsentative Untersuchung über Vergangenheitsbedeutung, Gegenwatwahrnehmungen und Zukunftserwarungen von Schülerinnen und Schülern in Ost-und Westdeutschland. Weinheim: Juventa.

Bourdieu, P. 1998. Teorie jednání. Praha: Karolinum.

BRUNER, J. 1990. Acts of Meaning. Cambridge, MA: Harvard University Press

DilTheY, W. (1910) 1981. Der Aufbau der geschichtlichen Welt in den Geisteswissenschaften. Frankfurt am Main : Suhrkamp.

GADAMER, H.-G. 1979. „The Problem of Historical Consciousness“. In: P. Rabinow, P. - Sullivan, W. M. /ed./, Interpretive Social Science: A Reader. Berkeley: University of Califorina: 103-160.

GeOrgi, V. B. - OHLIGER, R. 2009. Crossover Geschichte: Historisches Bewusstsein Jugendlicher in der Einwanderungsgesellschaft. Hamburg: Körber-Stiftung.

GIDDENS, A. 2000. Unikající svět: Jak globalizace mění náš život. Praha: Sociologické nakladatelství:

HALBWACHS, M. 1950. La mémoire collective. Paris: PUF.

HalbWachs, M. 1994. Les cadres sociaux de la mémoire. Paris: Albin Michel.

HeRVIEU-LÉGER, D. 1993. La Religion pour Mémoire. Paris: Le Cerf.

HrOCH, M. 2010. „Historické vědomí a potíže s jeho výzkumem dříve i nyní.“ In: Šubrt, J. (ed.), Historické vědomí jako předmět předmět badatelského zájmu: Teorie a výzkum. Kolín: Historická sociologie - knižní řada, S. $31-46$.

JEISMANN, K.-E. 1988. „Geschichtsbewußtsein als zentrale Kategorie der Geschichtsdidaktik." In.: Schneider G. /ed./, Geschichtsbewußtsein und historisch-politisches Lernen. Pfaffenweiter: Centaurus, 1-24.

KVASNIČKOVÁ, A. 2005. Náboženstvo jako kolektívna pamět: prípad Slovenska a Čiech. Bratislava: Univerzita Komenského.

LUHMANN, N. 1988. Soziologische Aufklärung. Bd. 2, Opladen: Westdeutscher Verlag. LYOTARD, J.-F. 1993. O postmodernismus. Praha: Filosofia.

MEAD, G. H. 1936. Movements of Thought in the Nineteenth Century. Ed. by M. H. Moore. Chicago: The University of Chicago Press. 
MEAD, G. H. 1959. The Philosphy of the Present. Ed. by A. E. Murphy. La Salle - Ill.: Open Court.

NAMER, G. 1987. Mémoire et société. Paris: Méridiens Klincksieck.

NAMER, G. 2000. Halbwachs et la mémoire sociale. Paris: L'Harmattan.

NorA P. (ed.) 1984. Les lieux de mémoire. I - La République. Paris: Gallimard.

OLICK, J. K. 2007. The Politics of Regret. New York: Routledge.

Olick, J. K. - VinitZKY-SEROUSSI, V. - LEVY, D. 2011. The Collective Memory Reader. Oxford: Oxford University Press.

PANDEL, H. J. 1987. „Dimensionen des Geschichtsbewustßtsein.“ In: Geschichtsdidaktik 2, Jg. 12, 130-142.

PARSONS, T. 1971. Společnosti: Vývojové a srovnávaci hodnocení. Praha: Svoboda.

RICOEUR, P. 2000. La mémoire, l'histoire, l'oubli. Paris: Seuil.

RÜSSEN, J. 1994. Historische Orientierung: Über die Arbeit des Geschichtsbewußtsein, sich in der Zeit zurechtzufinden. Köln: Böhlau.

RÜSSEN, J. 2001. Geschichtsbewußtsein: psychochologische Grundlagen, Entwicklungskonzepte, empirische Befunde. Köln: Böhlau.

RÜSEN, J. 2004. „Historical Consciousness: Narrative Structure, Moral Funciton, and Ontogenetic Development.“ In: Seixas, P. /ed./, Theorizing Historical Consciousness. Toronto. University of Toronto Press: 63-85.

SARBIN, T.R. /ed./ 1986. Narrative Psychology: The Storied Nature of Human Conduct. New York: Praeger.

SEIXAS, P. /ed./ 2004. Theorizing Historical Consciousness. Toronto. University of Toronto Press.

STRAUB, J. 2005. „Telling Stories, Making History: Toward a Narative Psychology of the Historical Construction of Meaning. In.: Straub, J. /ed./, Narration, Identity, and Historical Consciousness. New York, Oxford: Berghahn Books: 44-98.

STRAUB, J. /ed./ 1998. Erzählung, Identität und historisches Bewusstsein. Die psychologische Konstruktion von Zeit und Geschichte. Frankfurt am Main: Suhrkamp.

ŠUBRT, J. /ed./ 2010. Historické vědomí jako předmět badatelského zájmu: teorie a výzkum. Kolín: Historická sociologie

ŠubrT, J., PfeIferovÁ, Š. (2010). „Kolektivní pamět’ jako předmět historickosociologického bádání.“ In: Historická sociologie. 1/ 2010. Vol. 2.: 9-29.

ThOMAs W. I., 1965. Person und Sozialverhalten. Berlin: Luchterhand.

TODOROV, T. 1998. „Zneužívání paměti.“ In: Antologie francouzských společenských věd: Politika paměti. Cahiers du Cefres 13: 91-117.

Uledov, A. K. (1973). Struktura společenského vědomí. Praha: Svoboda.

VANĚK, J. (1980). Teorie společenského vědomi. Praha: Panorama.

Jiř́ Šubrt founded and since 2009 has been leader of the Department of Historical Sociology at the Faculty of Humanities of Charles University in Prague. He is the author and editor of several books published in the Czech language, which mainly deal with the theme of contemporary sociological theory, particularly with regard to issues of action, structure and social systems. Over the longer term he has also paid attention to the issues of time and memory, recently implementing a three year project focused on the 
empirical research of the historical consciousness of the Czech population. In the area of historical sociology he has focused on the problems of the civilization process, civilizational comparative analysis, social change and multiple modernities.

Doc. PhDr. Jiř́ Šubrt, CSc. Faculty of Humanities of Charles University U Krríže 8, 15800 Prague 5 Czech Republic E-mail: jiri.subrt@fhs.cuni.cz 